\title{
Manajemen Bandwidth Berdasarkan Prediksi Perilaku Pengguna Pada Jaringan TCP/IP Dengan Jaringan Syaraf Tiruan
}

\author{
Rama Beta Herdian ${ }^{1}$, Lie Jasa ${ }^{2}$, Linawati ${ }^{3}$ \\ Submission: 11-02-2020, Accepted: 15-06-2020
}

\begin{abstract}
User behavior prediction on TCP / IP networks is very possible because each data packet is passed through a router that can be analyzed and then classified into several behavior types from commonly performed activities by internet users. User-behavior predictions developed using artificial neural networks (ANN), which can show accurate results in predicting the bandwidth used by users in the next few days. Predicting results helps network administrators to provide a more accurate picture of user behavior patterns in the future, where the Personnel Service Application System (SAPK) which becomes the user behavior internet priority it's only utilized network resources at $26.8 \%$ of the total internet network resources available. The ANN that was developed also showed that $40.3 \%$ of network resources were used more by streaming video activities and $37 \%$ were used for streaming audio activities. With the prediction result, the network administrator rearranges the internet network resources distribution by applying a new prediction results pattern. This study conclusively shows that user behavior with streaming video activities is the largest bandwidth user and needs to get special attention on the internet network at the Regional X National Civil Service Agency Office.
\end{abstract}

Keyword - prediction, ANN, user behavior, bandwidth, internet

Intisari- Prediksi perilaku pengguna pada jaringan TCP/IP dapat dilakukan dengan menganalisa setiap paket data yang melalui router, kemudian mengklasifikasikannya kedalam beberapa jenis perilaku dari aktifitas yang umum dilakukan oleh pengguna internet. Prediksi perilaku pengguna menggunakan jaringan syaraf tiruan (JST) menunjukkan hasil yang akurat dalam memprediksi bandwitdth yang digunakan pengguna, serta memberikan gambaran pola perilaku pengguna dalam beberapa hari kedepan. Administrator jaringan akan mudah melakukan kontrol jaringan serta membuat keputusan lebih cepat dalam menentukan koneksi prioritas maupun yang bukan prioritas. Penelitian yang dikembangkan menunjukkan hasil, dimana Sistem Aplikasi Pelayanan Kepegawaian(SAPK) adalah koneksi prioritas perilaku pengguna internet di Kantor Regional X BKN hanya memanfaatkan sumber daya internet sebesar $26,8 \%$ dari keseluruhan sumber daya jaringan internet yang tersedia. Hasil prediksi menunjukkan $40,3 \%$ sumber daya internet lebih banyak digunakan aktifitas streaming video, dan $37 \%$

${ }^{1}$ Kasie Pemanfaatan Teknologi Informasi Kanreg X BKN, Mahasiswa Pasca Sarjana Jurusan Bisnis Telekomunikasi Universitas Udayana, Jl. PB Sudirman Denpasar Bali 80232, INDONESIA (tlp: $\quad$ 0361-720302; rama_beta@yahoo.com)

${ }^{2,3}$ S Dosen Magister Teknik Elektro, Universitas Udayana, Jl. PB Sudirman Denpasar Bali 80232, INDONESIA (tlp: 0361239599; e-mail: liejasa@unud.ac.id,linalwati@gmail.com digunakan aktifitas streaming audio. Berdasarkan hasil prediksi tersebut, administrator jaringan mengatur kembali sumber daya jaringan internet dengan alokasi bandwidth setiap jenis perilaku pengguna internet berdasarkan pola baru dari hasil prediksi, yakni alokasi sumber daya jaringan sebesar 50\% untuk koneksi SAPK dan $\mathbf{5 0 \%}$ berikutnya dialokasikan penggunaan selain SAPK. Kesimpulan penelitian ini menunjukkan bahwa perilaku pengguna dengan aktifitas streaming video merupakan pengguna bandwidth terbesar pada jaringan internet di Kantor Regional X BKN.

Kata Kunci- prediksi, JST, perilaku pengguna, bandwidth, Internet.

\section{Pendahuluan}

Peningkatan pemanfaatan sumber daya jaringan yang sangat cepat merupakan hal yang harus diperhatikan oleh pengelola jaringan. Saat ini jaringan komputer berkembang pesat dan semakin kompleks. Aliran data yang dominan membebani jaringan komputer sebesar $80 \%$ dari total lalu lintas jaringan adalah layanan peer to peer (P2P)[1] yang merupakan aplikasi file berbagi pakai serta aplikasi streaming video, contohnya seperti Youtube.

Pengalamatan host dan perangkat yang tidak sesuai persyaratan yang telah ditentukan oleh pengelola jaringan, serta perilaku pengguna jaringan yang tidak bertanggung jawab sering menyebabkan terjadinya kegagalan dalam komunikasi data. Pengguna jaringan dengan perilaku yang kompleks dalam memanfaatkan sumber daya jaringan juga berdampak besar pada pengguna jaringan lainnya dan perangkat-perangkat di dalam jaringan[2], tren baru seperti penggunaan streaming video dan cloud sharing juga membebani jaringan serta menyebabkan performa jaringan menjadi menurun[3].

Pembatasan bandwidth yang diterapkan administrator kepada setiap pengguna jaringan dirasakan belum efektif dalam hal mengatur pemanfaatan sumber daya jaringan, karena kebutuhan pengguna juga meningkat tanpa diikuti dengan ketersediaan bandwidth yang ada saat ini[4]. Bagi pengelola jaringan sangatlah penting dalam memahami perilaku pengguna pada jaringan komputer yang dikelolanya, perilaku pengguna tersebut diwakili aktivitas pengguna jaringan dengan berbagai jenis aplikasi dan program yang dicirikan oleh penentuan aktifitas protokol dan port[5]. Penggunaan port dan protokol adalah suatu event, semua event tersebut dicatat oleh sistem pada router untuk mendeteksi perilaku pengguna yang tidak normal. Mengingat perilaku pengguna yang tidak normal memiliki banyak cara yang rumit dan terus berevolusi guna memaksimalkan 
bandwidth yang diperoleh, semisal menghapus atau mengganti data sensitif.

Sebuah sistem untuk mendeteksi perilaku pengguna sangat penting, karena akan memberikan visibilitas dan kontrol yang lebih besar untuk keamanan jaringan, sistem ini memungkinkan administrator jaringan untuk mengamati kejadian secara real time, baik dari sistem operasi komputer maupun dari perangkat keamanan lainnya di dalam jaringan, peristiwa ini terpusat, berkorelasi dan tersimpan dalam database sistem untuk mendeteksi perilaku pengguna yang tidak normal.

Penelitian terhadap perilaku pengguna jaringan selama ini masih jarang dilakukan, sebagian besar peneliti lebih serius mengamati dan melakukan pengukuran terhadap QoS(Quality of Service) dan QoE(Quality of Experience), sedangkan perilaku dan kebiasaan pengguna jaringan merupakan salah satu hal penting yang mempengaruhi $Q o S$ dan $Q o E$. Beberapa penelitian terhadap perilaku pengguna jaringan sebelumnya yang pernah diusulkan adalah untuk mengetahui perilaku pengguna jaringan dengan menerapkan metode $T F$ IDF(Term Frequency - Inverse Document Frequency[5] terhadap data internet browsing yang diperoleh dari jaringan WiFi untuk menampilkan implikasi secara nyata terhadap hasil pengelompokan terhadap dokumen dan model pengguna jaringan. Dari penerapan metode tersebut diperoleh pengelompokan perilaku pengguna yang lebih detil serta dapat mengekstraksi kebiasaan pengguna yang tersembunyi pada saat melakukan browsing dengan pemilahan kemiripan pengguna kedalam beberapa kelompok perilaku pengguna jaringan.

Sinha[6] mempelajari perilaku pengguna internet dengan membandingkan dua perbedaan upstream link dari teknologi Broadband Fixed Wireless $(B F W)$ dan Digital Subscriber Lines (DSL), dimana kecepatan download lebih tinggi daripada upload. Analisa yang digunakan adalah dengan menggunakan packet trace dan data NetFlow yang menampilkan aliran data yang dihasilkan dari aplikasi NetFlow. Pada sisi uplink yang singkat, diketahui keduanya mengakses jaringan dan menunjukkan bahwa sebagian besar disebabkan oleh aktifitas download melalui protokol TCP $A C K$ terutama layanan $H T T P$ dan $P 2 P$, selain itu adalah paket kontrol TCP (SYN, RST, FIN) dan permintaan DNS. Penelitian tersebut bisa dilihat sebagai langkah awal dalam membuat model parametrik umum untuk akses jaringan broadband.

Penelitian yang dilakukan oleh Marques dkk[7], pertamatama memisahkan aliran pengguna kedalam dua kategori yakni kategori pengguna perumahan dan kategori pengguna bisnis, kemudian dilakukan analisa terhadap session arrival dan durasi pengguna serta menyimpulkan bahwa hal tersebut mengikuti proses eksponensial dan lognormal untuk masingmasing pengguna perumahan maupun pengguna bisnis. Marquez dkk juga menganalisis profil berbagai jenis aplikasi, seperti web Peer-to-Peer, Instant Messaging dan POP3. Kontribusi lainnya adalah pengajuan terhadap Customer Behaviour Model Graph yang terdiri dari grafik transisi negara yang terbagi kedalam kelas yang mencoba memodelkan perilaku pengguna, terutama pola permintaan pengguna.

Berdasarkan penelitan-penelitian sebelumnya dan beberapa permasalahan yang telah diuraikan di atas, penulis merumuskan beberapa masalah dalam penelitian ini, antara lain adalah bagaimana menentukan kebutuhan bandwidth yang tepat untuk Aplikasi Pelayanan Kepegawaian (SAPK) berdasarkan prediksi perilaku pengguna jaringan internet dengan metode Jaringan Syaraf Tiruan (JST), serta bagaimana hasil prediksi dapat digunakan untuk merencanakan kebutuhan sumber daya jaringan internet untuk Kantor Regional X Badan Kepegawaian Negara kedepannya.

\section{Metode Penelitian}

Pada penelitian ini digunakan beberapa metode dalam menganalisa dan melakukan prediksi terhadap perilaku pengguna internet sebagai berikut :

\section{A. Perilaku Pengguna (use behavior) dan Analisis Perilaku}

Perilaku penggunaan teknologi informasi sangat bergantung pada evaluasi pengguna dari sebuah sistem, dengan kata lain, penggunaan sistem adalah indikator dari kesuksesan dan penerimaan teknologi informasi[8]. Variabel perilaku penggunaan (use behavior) menggunakan data primer yang berasal dari tabel firewall dari sistem router OS Mikrotik. Sistem Operasi Mikrotik yang digunakan dalam penelitian ini akan mengukur dengan menggunakan instrumen data yang terdiri dari (1) Alamat IP Address user/workstation (2) Bandwitdh yang digunakan (3) Intensitas Upload dan Download (4) Intensitas tiap jenis perilaku pengguna internet.

Analisis perilaku berfokus pada pemahaman bagaimana konsumen atau pengguna bertindak dan mengapa, memungkinkan prediksi yang akurat tentang bagaimana pengguna akan bertindak di masa depan. Hal ini memungkinkan administrator untuk membuat keputusan yang tepat untuk segmen koneksi data yang tepat pada waktu yang tepat.

Analisis perilaku memanfaatkan data mining pengguna yang ditangkap selama sesi di mana konsumen menggunakan aplikasi, permainan, atau situs web, termasuk lalu lintas data seperti jalur navigasi, even klik, interaksi media sosial, dan jumlah waktu yang dihabiskan di situs web. Poin data ini kemudian dikumpulkan dan dianalisis, sehingga dengan melihat perkembangan sesi dari ketika pengguna pertama kali memasuki platform sampai koneksi dibuat, analisis perilaku memungkinkan tindakan dan tren masa depan akan diprediksi berdasarkan pengumpulan data tersebut.

\section{B. Jaringan Syaraf Tiruan (JST)}

Jaringan Syaraf Tiruan (JST) terdiri dari set neuron yang saling berhubungan secara dekat. Jaringan neuron mampu melakukan tugas yang sangat kompleks seperti klasifikasi dan pemahaman pola[9]. JST dapat memperkirakan rentang yang cukup luas pada suatu model statistika dan fleksibel dalam menggambarkan model (linear maupun non linear). JST dapat digunakan untuk permasalahan statistika multivariat seperti multiple regression, Analisa deskriminan dan Analisa kluster. Dalam banyak kasus, hasil Analisa dengan JST dapat dibandingkan dengan model statistika multivariat.

Terdapat tiga jenis utama JST yakni Multilayer Perception, Radial Basis Function, dan Kohonen Network[10]. Penelitian ini menggunakan metode Multilayer Perception, karena model tersebut umum digunakan untuk melakukan prediksi pada perilaku pengguna suatu layanan. 
Multilayer Perception merupakan model yang memetakan suatu set input data menjadi set output, dengan menggunakan fungsi aktivasi non linear. Pada Multilayer Perception variabel independen maupun dependen dapat memiliki tingkat pengukuran metrik maupun nonmetrik. Multilayer Perception merupakan feedforward neural network dimana informasi bergerak hanya dalam satu arah, dari simpul input melalui simpul tersembunyi dan simpul output.

\section{Algoritma Pembelajaran}

Jaringan Syaraf memperoleh nilai bobot dari suatu algoritma pembelajaran tertentu. Bobot ini digunakan dalam melakukan transformasi nilai dari node input ke node output. Algoritma pembelajaran merupakan tahap penyesuaian terhadap bobot yang telah terbentuk secara random[11]. Pembaharuan nilai bobot secara umum dirumuskan sebagai berikut :

$$
W i j(n+1)=W i j(n)+\Delta W i j(n)
$$

dimana $\Delta$ wij(n) dihitung dengan algoritma pembelajaran dan $W_{i j}(n)$ merupakan bobot awal yang ditentukan secara acak pada tahap inisialisasi.

\section{Algoritma Backpropagation.}

Masukan dari node input diteruskan ke hidden layer kemudian dilanjutkan ke node output. Setiap hubungan dari unit $i$ ke unit $j$ memiliki bobot $W i j$ yang mengindikasikan kekuatan dari koneksi. Jumlah dari pembobotan, $a j$, untuk sebuah input $X i j$ dan bobot Wij didefinisikan sebagai berikut[10] :

$$
a_{\mathrm{j}}=\sum_{i=1}^{n} \mathrm{~W}_{\mathrm{ij}} \mathrm{X}_{\mathrm{i}}
$$

dimana nilai $n$ merupakan jumlah input pada suatu neuron. Fungsi aktivasi yang digunakan adalah fungsi aktivasi logistic sigmoid.

$$
\mathrm{g}(a)=\frac{1}{1+e^{a}}
$$

Nilai galat, $E_{j}(n)$, antara output aktual $y_{j}(n)$ dan nilai output dari neuron $d_{j}(n)$ dihitung dengan rumus :

$$
E_{j}(n)=d_{j}(n)-y_{j}(n)
$$

Rumus pembelajaran dengan Backpropagation adalah :

$$
\Delta W_{i j}=\eta X_{i}+\alpha \Delta W_{i j}=\eta X_{i}-\alpha \frac{\delta E_{j}}{\delta W_{\mathrm{ij}}} .
$$

Dimana $\eta$ adalah laju pembelajaran (learning rule) dan $\alpha$ adalah faktor moment. Parameter tersebut menentukan seberapa besar pengaruh parameter lama terhadap arah perubahan parameter yang baru.

Dengan melakukan proses belajar, jaringan syaraf dapat memodifikasi tingkah laku sesuai dengan keadaan lingkungannya. Jaringan syaraf dapat mengatur dirinya untuk menghasilkan suatu respon yang konsisten terhadap rangkaian masukan[12]. Jaringan syaraf tiruan dirancang dan dilatih untuk memiliki kemampuan seperti yang dimiliki manusia.
Otak sebagai pengolah sistem Informasi. Gambar 1 adalah model Jaringan Syaraf Tiruan dengan propagasi balik yang digunakan pada penelitian ini.

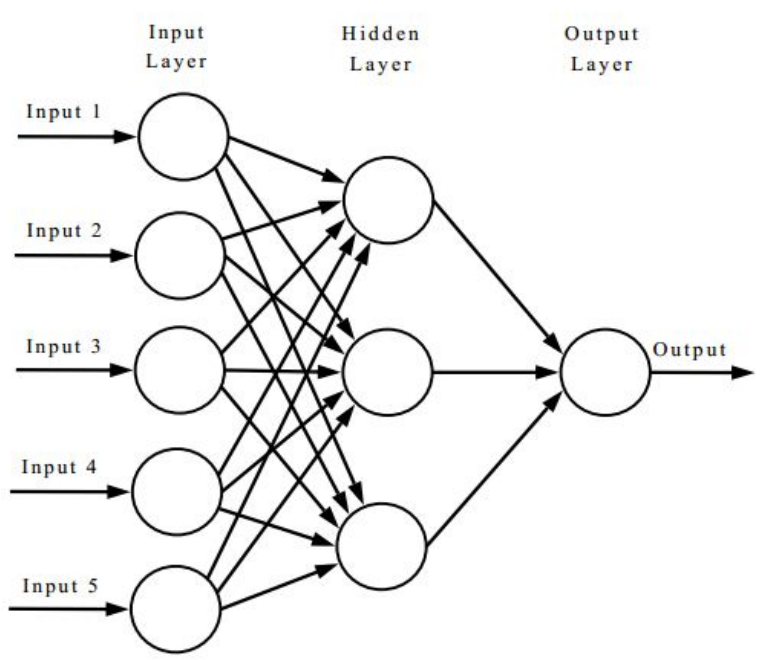

Gambar 1: Tipe feedforward neural network (MLP).

\section{Transformasi Data.}

Data yang dikumpulkan tidak dapat langsung digunakan pada metode atau teknik yang akan diterapkan. Data harus dilakukan praprosesing terlebih dahulu. Tahap ini dilakukan untuk mendapatkan hasil analisis yang lebih akurat dalam pemakaian teknik-teknik pembelajaran mesin (machine learning) atau data mining.

Dalam beberapa hal, praprosesing dapat membuat nilai data menjadi lebih kecil tanpa merubah informasi yang dikandungnya. Ada beberapa cara transformasi data yang dilakukan sebelum menerapkan suatu metode, antara lain adalah normalisasi atau scaling.

Transformasi data adalah prosedur mengubah data sehingga berada dalam skala tertentu. Skala ini bisa antara $(0-1),(-1-$ 1) atau skala lain yang diinginkan. Misalkan akan mentransformasikan data bandwidth jaringan internet, maka data bandwidth tersebut akan dikonversi ke dalam skala atau rentang nilai antara 0 sampai dengan 1 . Dalam hal ini batas bawah (BB) adalah 0 dan batas atas (BA) adalah 1, jika nilai maksimum tiap kolom adalah Xmax dan nilai mnimumnya adalah Xmin, untuk mengubah data ke skala baru tersebut, maka digunakan rumus[13] :

$$
X^{1}=\frac{X-X \min }{X \max -X \min } *(B A-B B)+B B \ldots \ldots \ldots \ldots
$$

Jaringan syaraf tiruan propagasi balik (backpropagation) dilatih dengan metode belajar terbimbing. Dalam metode ini jaringan diberi sekumpulan pasangan pola yang terdiri dari pola masukan dan pola yang diinginkan[14]. Pelatihan dilakukan secara berulang-ulang sehingga dihasilkan jaringan yang memberikan tanggapan yang benar terhadap semua masukannya.

Rama Beta Herdian: Manajemen Bandwidth Berdasarkan Prediksi... 
Perhitungan kesalahan (error) merupakan pengukuran bagaimana jaringan dapat belajar dengan baik, sehingga jika dibandingkan dengan pola yang baru akan dengan mudah dikenali. Kesalahan (error) pada keluaran jaringan merupakan selisih antara keluaran sebenarnya (current output) dan keluaran yang diinginkan (desired output) atau target yang diinginkan[15]. Selisih yang dihasilkan antara keduanya biasanya ditentukan dengan cara dihitung mengunakan persamaan :

\section{- Sum Square Error (SSE)}

$$
S S E=\sum_{p} \sum_{j}(T j p-Y j p)
$$

- Mean Square Error (MSE)

$$
M S E=\frac{S S E}{n p \cdot n j}
$$

\section{- Root Mean Square Error (RMSE)}

$$
R M S E=\sqrt{M S E}
$$

Dimana :

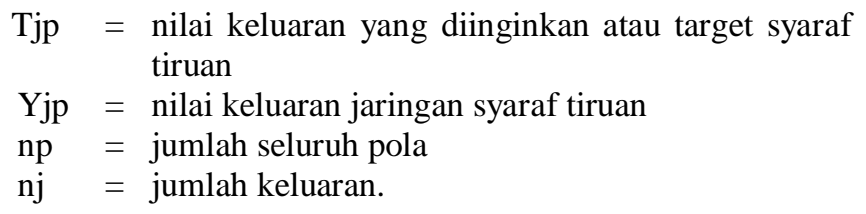

\section{HASIL DAN PEMBAHASAN}

\section{A. Analisa Jaringan}

Tahapan analisa jaringan dilakukan dengan cara melakukan inventarisir seluruh IP address pengguna yang berada pada jaringan utama Kantor Regional X BKN dengan tool firewalladdress list pada Mikrotik Router OS[15], kemudian menambahkan properti untuk setiap IP address berupa nama penanggung jawab IP/perangkat, nama perangkat, dan nama ruangan dimana perangkat tersebut digunakan.

Tahap berikutnya adalah mendeskripsikan topologi jaringan $L A N$ yang digunakan di Kantor Regional X BKN, sesuai hasil identifikasi, jaringan $L A N$ di Kantor Regional $\mathrm{X}$ BKN menggunakan topologi star dengan menggunakan beberapa switch untuk membagi jaringan yang ditunjukkan pada Gambar 2 berikut.

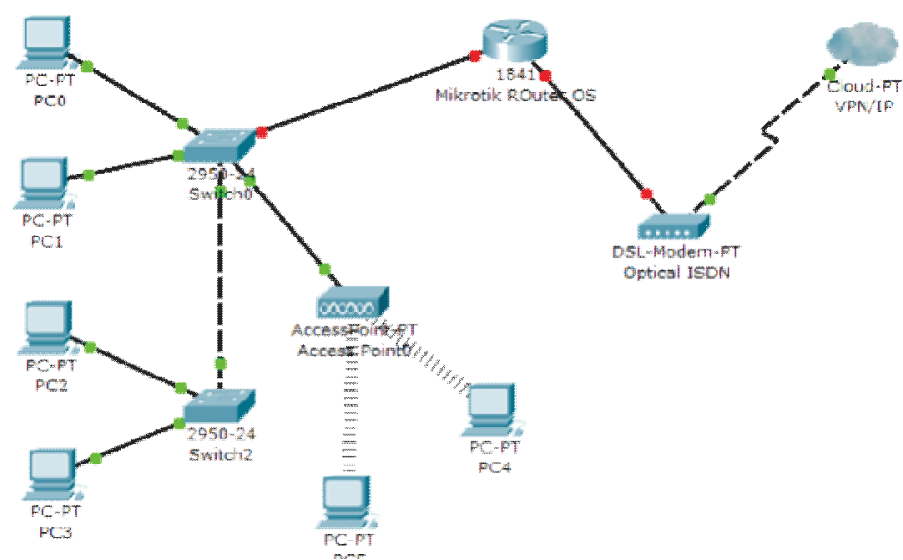

Gambar 2. Arsitektur jaringan Kantor Regional X BKN

ISSN $1693-2951$
Sistem Aplikasi Pelayanan Kepegawaian (SAPK) menjadi prioritas dalam penggunaan sumber daya jaringan internet di Kantor Regional X BKN. Aplikasi yang digunakan maupun yang diakses pada Kantor Regional X BKN keseluruhannya menggunakan jaringan internet. Sumber daya internet di Kantor Regional X BKN disediakan oleh BKN Pusat di Jakarta dengan menggunakan jaringan Virtual Private Network (VPN) dengan bandwidth 10 MBps.

Kondisi arus lalu lintas jaringan yang padat dapat mengganggu performa SAPK, sehingga diperlukan kontrol dan pengamatan yang terjadwal untuk menjamin kesetabilan koneksi terhadap SAPK.

Analisa jaringan menunjukkan manajemen jaringan pada jaringan LAN Kantor Regional $\mathrm{X}$ BKN menggunakan pembagian bandwidth dengan sistem load balance. Sistem ini membagi bandwidth secara seimbang terhadap keseluruhan pengguna, baik pengguna yang mengakses aplikasi prioritas maupun pengguna yang mengakses selain aplikasi prioritas. Sistem load balance yang diterapkan tidak dapat memberikan jaminan terhadap akses kepada aplikasi yang menjadi prioritas dalam pemanfaatan sumber daya jaringan internet.

Dimensi pemanfaatan sumber daya jaringan di Kantor Regional X Badan Kepegawaian Negara dipengaruhi oleh beberapa faktor, yakni arus data (Flow), waktu (Time) dan Pengguna (User) yang ditunjukkan pada Gambar 3.

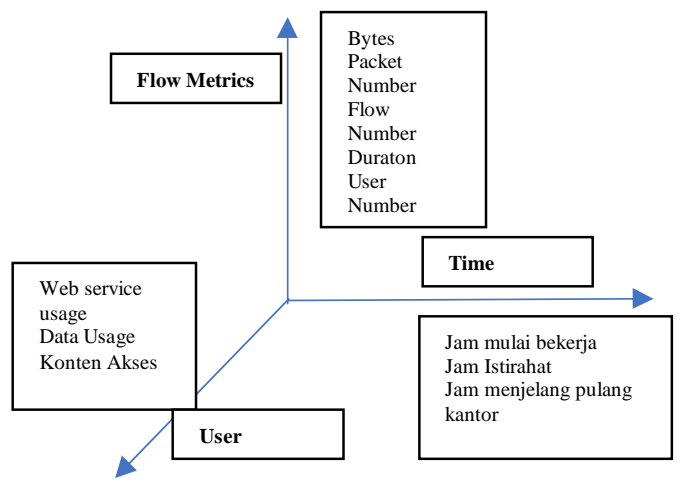

Gambar 3. Analisis Dimensi pada jaringan Internet Kantor Regional X BKN

Analisis dimensi pada jaringan internet di Kantor Regional $\mathrm{X}$ BKN bertujuan untuk mengetahui variabel-variabel yang berpengaruh pada manajemen pengguna jaringan internet serta untuk mengetahui pola perilaku yang akan didefinisikan kedalam beberapa jenis perilaku pengguna internet di Kantor Regional X BKN.

Tiga dimensi utama pada analisis dimensi jaringan internet Kantor Regional X BKN adalah Flow, Time dan User. Dimensi Flow merupakan gambaran dari arus data yang melalui router. Dimensi User merupakan variabel yang mewakili aktifitas pengguna selama mengakses suatu konten internet, sedangkan Time adalah variabel yang mewakili waktu pada saat data-data aktifitas pengguna internet diambil.

\section{B. Pengambilan Data}

Data lalu lintas pengguna jaringan diperoleh dengan menggunakan tools monitoring system traffict pada fitur firewall di router Mikrotik, dimana arus data diklasifikasikan kedalam 5 jenis kategori perilaku pengguna internet, yakni perilaku pengguna Download, perilaku pengguna Streaming Video, perilaku pengguna Streaming Audio, perilaku 
pengguna Media Sosial, perilaku pengguna e-Commerce dan perilaku pengguna Sistem Aplikasi Pelayanan Kepegawaian (SAPK).

Proses klasifikasi dilakukan dengan menandai setiap koneksi terhadap konten yang diakses oleh pengguna pada proses prerouting pada router mikrotik. Akses terhadap konten-konten yang mewakili setiap kategori kemudian dikelompokkan kedalam kategori-kategori yang mewakili perilaku pengguna internet di Kantor Regional X BKN. Pengelompokan perilaku pengguna ditampilkan Tabel 1 berikut :

TABEL I

KLASIFIKASI PERILAKu PENGGUNa Berdasarkan Konten YANG DIAKSES

\begin{tabular}{|c|c|c|c|}
\hline Jenis Perilaku & $\begin{array}{c}\text { url / Jenis file / Data / } \\
\text { Konten }\end{array}$ & Keterangan & $\begin{array}{l}\text { Durasi } \\
\text { sampel }\end{array}$ \\
\hline $\begin{array}{l}\text { SAPK (Sistem } \\
\text { Aplikasi Pelayanan } \\
\text { Kepegawaian) } \\
\text { perilaku pengguna } \\
\text { internet dengan } \\
\text { aktifitas } \\
\text { menggunakan } \\
\text { aplikasi pelayanan } \\
\text { kepegawaian. } \\
\text { sebagai aplikasi } \\
\text { utama yang } \\
\text { digunakan di BKN }\end{array}$ & $\begin{array}{l}\text { - https://sapk.bkn.go.id } \\
\text { - https://hr.bkn.go.id } \\
\text { - https://pdm.bkn.go.id } \\
\text { - https://bkn.go.id } \\
\text { - https://denpasar.bkn. } \\
\text { go.id }\end{array}$ & $\begin{array}{l}\text { Konten utama } \\
\text { yang } \\
\text { mendapat-kan } \\
\text { prioritas utama } \\
\text { dalam } \\
\text { pemanfaatan } \\
\text { bandwidth } \\
\text { pada jaringan } \\
\text { LAN BKN }\end{array}$ & $\begin{array}{c}60 \\
\text { menit }\end{array}$ \\
\hline $\begin{array}{l}\text { Streaming video } \\
\text { (perilaku pengguna } \\
\text { internet dengan } \\
\text { aktifitas streaming } \\
\text { video, mengunduh } \\
\text { file video) }\end{array}$ & $\begin{array}{l}\text { - https://youtube.com } \\
\text { File mp4, mpeg, mpg, } \\
\text { avi, flv, mkv }\end{array}$ & $\begin{array}{l}\text { Konten video, } \\
\text { streaming file } \\
\text { video dan } \\
\text { download file } \\
\text { jenis video }\end{array}$ & $\begin{array}{c}60 \\
\text { menit }\end{array}$ \\
\hline $\begin{array}{l}\text { Streaming audio } \\
\text { (perilaku pengguna } \\
\text { internet dengan } \\
\text { aktifitas streaming } \\
\text { audio, radio } \\
\text { online, dan } \\
\text { mengunduh file } \\
\text { audio) }\end{array}$ & $\begin{array}{l}\text { https://www.spotify.co } \\
\text { m } \\
\text { https://www.joox.com } \\
\text { https://radio.garden } \\
\text { File : ogg, wav, mp3 }\end{array}$ & $\begin{array}{l}\text { Konten audio } \\
\text { streaming, dan } \\
\text { file audio } \\
\text { yang umum } \\
\text { digunakan } \\
\text { streaming } \\
\text { audio }\end{array}$ & $\begin{array}{c}60 \\
\text { menit }\end{array}$ \\
\hline $\begin{array}{l}\text { Media Sosial } \\
\text { (perilaku pengguna } \\
\text { internet dengan } \\
\text { aktifitas media } \\
\text { sosial) }\end{array}$ & $\begin{array}{l}\text { https://www.facebook. } \\
\text { com } \\
\text { https://www.instagram. } \\
\text { com } \\
\text { https://www.twitter. } \\
\text { com } \\
\text { - https://www.whatsapp. } \\
\text { com }\end{array}$ & $\begin{array}{l}\text { Konten atau } \\
\text { data yang } \\
\text { diambil dari } \\
\text { aktifitas akses } \\
\text { situs-situs } \\
\text { media sosial }\end{array}$ & $\begin{array}{c}60 \\
\text { menit }\end{array}$ \\
\hline $\begin{array}{l}\text { e-Commerce } \\
\text { (perilaku } \\
\text { pengguna internet } \\
\text { dengan aktifitas } \\
\text { belanja on line) }\end{array}$ & $\begin{array}{l}\text { https://tokopedia,com } \\
\text { https://bukalapak.com } \\
\text { https://jakartanoteboo. } \\
\text { com } \\
\text { https://bhineka.com } \\
\text { https://shopee.com } \\
\text { https://elevenia.co.id } \\
\text { https://jd.id } \\
\text { https://lazada.com }\end{array}$ & $\begin{array}{l}\text { Konten atau } \\
\text { data yang } \\
\text { diambil dari } \\
\text { aktifitas akses } \\
\text { ke situs-situs } \\
\text { e-commerce }\end{array}$ & $\begin{array}{c}60 \\
\text { menit }\end{array}$ \\
\hline $\begin{array}{l}\text { Download } \\
\text { (perilaku pengguna } \\
\text { internet dengan } \\
\text { aktifitas download) }\end{array}$ & $\begin{array}{l}\text { File : RAR, ZIP,EXE } \\
\text { FTP } \\
\text { Penggunaan } \\
\text { accelerator download }\end{array}$ & $\begin{array}{l}\text { Konten atau } \\
\text { data yang } \\
\text { diambil dari } \\
\text { aktifitas } \\
\text { download }\end{array}$ & $\begin{array}{c}60 \\
\text { menit }\end{array}$ \\
\hline
\end{tabular}

TABEL 2

CONTOH DATA RATES YANG DiAMBIL BERDASARKAN WAKTU YANG MEWAKILI AKTIFITAS PERILAKu PENGguna INTERNET

\begin{tabular}{|l|r|r|r|}
\hline \multirow{2}{*}{$\begin{array}{c}\text { Jenis perilaku } \\
\text { pengguna } \\
\text { internet }\end{array}$} & \multicolumn{3}{|c|}{ Jumlah data } \\
\cline { 2 - 4 } & Bute $(M b) /$ Rerata Rates(Kbps) \\
\cline { 2 - 4 } & $82.60 / 192,6$ & $270.00 / 337,3$ & $343.60 / 814,5$ \\
\hline SAPK & $1,466.70 / 260,4$ & $2,323.80 / 422,0$ & $2,849.60 / 814$ \\
\hline $\begin{array}{l}\text { Streaming } \\
\text { video }\end{array}$ & $23.20 / 234,80$ & $107.90 / 391.0$ & $117.20 / 942,3$ \\
\hline $\begin{array}{l}\text { Streaming } \\
\text { audio }\end{array}$ & $79.90 / 104,0$ & $270.00 / 63,70$ & $625.90 / 1,36$ \\
\hline Media sosial & $20.80 / 42,10$ & $184.90 / 122,90$ & $421.10 / 2,10$ \\
\hline e-Commerce & $52.28 / 20,0$ & $287.50 / 191,90$ & $371.30 / 83,90$ \\
\hline Download & \multicolumn{3}{|c}{} \\
\hline
\end{tabular}

Data rates pada Tabel 2 diatas adalah jumlah dalam satuan megabyte $(M b)$ data yang menggambarkan penggunaan internet oleh setiap jenis perilaku pengguna internet selama waktu tertentu.

TABEL 3

CONTOH DATA JUMLAH PACKET YANG DIAMBIL BERDASARKAN WAKTU YANG MEWAKILI AKTIFITAS PERILAKU PENGGUNA INTERNET

\begin{tabular}{|l|r|r|r|}
\hline \multirow{2}{*}{$\begin{array}{c}\text { Jenis perilaku } \\
\text { pengguna internet }\end{array}$} & \multicolumn{3}{|c|}{ Jumlah packet } \\
\cline { 2 - 4 } & Pukul 09.00 & Pukul 13.00 & \multicolumn{1}{|c|}{ Pukul 15.00 } \\
\cline { 2 - 4 } & 674,209 & $2,041,682$ & $2,626,583$ \\
\hline SAPK & $3,748,562$ & $9,756,583$ & $12,472,268$ \\
\hline Streaming video & 291,377 & $1,263,213$ & $1,318,568$ \\
\hline Streaming audio & 8,799 & $1,355,636$ & $2,759,073$ \\
\hline Media sosial & 162,387 & $1,381,942$ & $2,367,148$ \\
\hline e-Commerce & 679,075 & $3,332,405$ & $3,442,212$ \\
\hline Download & & & \\
\hline
\end{tabular}

Sedangkan data jumlah packet dalam Tabel 3, merupakan jumlah paket data yang ditangkap oleh firewall Mikrotik berdasarkan setiap jenis perilaku pengguna internet yang diambil sesuai waktu yang telah ditentukan.

Rancangan Jaringan Syaraf Tiruan (JST) yang dikembangkan untuk melakukan prediksi bandwidth berdasarkan perilaku pengguna internet ditunjukkan dalam Gambar 4. berikut :

Rama Beta Herdian: Manajemen Bandwidth Berdasarkan Prediksi... 


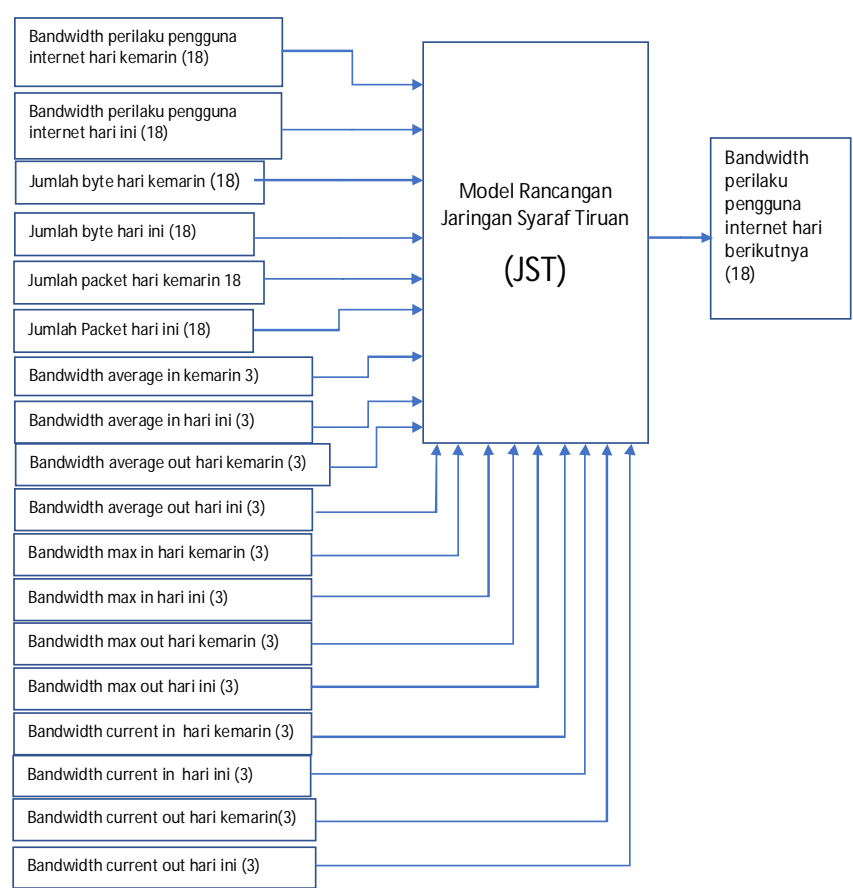

Gambar 4. Diagram blok model rancangan JST

\section{Evaluasi Hasil Prediksi.}

Unjuk kerja dari model JST yang dikembangkan setelah dilakukan pelatihan dapat diukur dengan melihat error atau MSE (Mean Square Error) dari hasil pelatihan, validasi dan pengujian terhadap sekumpulan data input baru.

Pelatihan algoritma propagasi balik (backpropagation) menggunakan metode pencarian dengan memperbaiki bobotbobot jaringan dengan arah yang membuat fungsi kinerja menjadi turun dengan cepat[10]. Pada proses pencarian dikenal 2 macam metode, yakni mode Incremental dan mode kelompok (Batch).

Dalam mode Incremental, perhitungan gradien dan perbaikan nilai bobot dilakukan pada setiap pengoperasian input data, sedangkan pada mode kelompok penghitungan gradien dan perbaikan nilai bobot dilakukan setelah pengoperasian semua input data. Error yang terjadi dalam setiap pola masukan dijumlahkan untuk menghasilkan bobot baru.

Metode yang paling sederhana untuk merubah bobot adalah metode penurunan gradien (gradient descent), fungsi ini dikenal sebagai Learngd, parameter yang berhubungan dengan Learngd yaitu learning rate, semakin besar nilai learning rate akan berdampak pada semakin besarnya langkah pembelajaran dan algoritma menjadi tidak stabil, sebaliknya jika learning rate terlalu kecil menyebabkan algoritma akan konvergen membutuhkan waktu yang lama.

Untuk mencapai konvergensi yang lebih cepat, model yang dikembangkan akan diatur pada parameter learning rate, jumlah neuron pada lapisan tersembunyi (hidden layer) serta dengan merubah fungsi pelatihan atau training function yakni (Traincgb, Traincgf, Traincgp, Traingd, Traingdm, Traingda dan Traingdx).

Jumlah data (pola data) yang digunakan dalam penelitian ini sebanyak 177 pola, dimana pelatihan dilakukan dengan menerapkan beberapa nilai besaran learning rate dan jumlah neuron hidden layer, pelatihan dilakukan dengan menentukan learning rate mulai $0.1,0.2,0.3, \ldots 1$ kemudian menentukan jumlah neuron hidden layer menggunakan kelipatan $6(6,12$, $18,24, \ldots 48)$.

Langkah berikutnya adalah melakukan pelatihan dengan parameter yang sama dan adaption parameter function yakni Learngd dengan menggunakan beberapa fungsi pelatihan yang berbeda yakni Traincgb, Traincgf, Traincgp, Traingd, Traingdm, Traingda dan Traingdx.

Setelah dilakukan beberapa kali percobaan pelatihan (trial and error) diperoleh kombinasi terbaik yakni nilai parameter learning rate 0,1 dan jumlah neuron hidden layer sebanyak 24 . Penentuan kombinasi terbaik didasari oleh nilai MSE (Mean Square Error) terkecil dan tingkat konvergensi yang semakin baik.

Pelatihan yang dilakukan dengan menerapkan beberapa fungsi pelatihan, dan hasil yang dianggap terbaik adalah fungsi dengan nilai MSE (Mean Square Error) terendah dan jumlah iterasi (epoch) paling sedikit, yakni JST fungsi pelatihan Traincgb dengan nilai $M S E=0,000000000067427$ dan jumlah iterasi sebanyak 61, Nilai bobot (weight) dari hasil pelatihan kemudian disimpan.

TABEL 4

UNJUK KERJA JST YANG DIKEMBANGKAN DENGAN BEBERAPA FUNGSI PELATIHAN

\begin{tabular}{|l|c|c|c|}
\hline \multicolumn{1}{|c|}{ Fungsi Pelatihan } & $\begin{array}{c}\text { Jumlah } \\
\text { Iterasi } \\
\text { (epoch) }\end{array}$ & $\begin{array}{c}\text { MSE (Mean Square } \\
\text { Error) }\end{array}$ & Keterangan \\
\hline $\begin{array}{l}\text { Traincgb } \\
\text { (powell-beale restart) }\end{array}$ & 61 & 0,00000000067427 & Konvergen \\
\hline $\begin{array}{l}\text { Trincgf } \\
\text { (gradient descent } \\
\text { dengan mengupdate } \\
\text { bobot dan bias) }\end{array}$ & 65 & 0,0000001363 & Konvergen \\
\hline $\begin{array}{l}\text { Traincgp } \\
\text { (Konjugasi } \\
\text { backpropagation } \\
\text { gradien dengan } \\
\text { pembaruan Polak- } \\
\text { Ribiére) }\end{array}$ & 50 & 0,000004326 & Konvergen \\
\hline $\begin{array}{l}\text { Traingd } \\
\text { (gradient descent) }\end{array}$ & 6000 & 0,000031357 & $\begin{array}{c}\text { Belum } \\
\text { konvergen }\end{array}$ \\
\hline $\begin{array}{l}\text { Traingdm } \\
\text { (gradient descent } \\
\text { dengan momentum) }\end{array}$ & 6000 & 0,00006324 & $\begin{array}{c}\text { Belum } \\
\text { konvergen }\end{array}$ \\
\hline $\begin{array}{l}\text { Traingda } \\
\text { (gradient descent } \\
\text { dengan adaptif } \\
\text { learning rate }\end{array}$ & 2467 & 0.000000009320 & $\begin{array}{c}\text { Belum } \\
\text { konvergen }\end{array}$ \\
\hline $\begin{array}{l}\text { Traingdx } \\
\text { gradient descent } \\
\text { dengan momentum } \\
\text { dan adaptif learning } \\
\text { rate } \text { ) }\end{array}$ & 0,00000002588 & $\begin{array}{c}\text { Belum } \\
\text { konvergen }\end{array}$ \\
\hline
\end{tabular}

Keterangan seting parameter pelatihan :

- Learning rate $\quad: 0.1$

- Hidden layer : : 24

- Maksimum kesalahan : 10000

- Jumlah Iterasi (epoch) : 6000

- Jumlah hidden layer : 10

\section{Pengujian Jaringan Syaraf Tiruan (JST)}

Pengujian terhadap model JST yang dibangun adalah dengan memberikan pola masukan data baru yang belum 
pernah digunakan pada proses pelatihan, Data baru yang selanjutnya disebut data uji adalah data yang sebelumnya telah dipisahkan pada tahap praproses data.

Data uji yang dimasukkan kedalam model JST adalah data yang mewakili setiap perilaku pengguna jaringan yakni : jumlah packet, jumlah bytes, average bandwidth (in/out), maximum bandwidth (in/out), current bandwidth (in/out), SAPK, streaming video, streaming audio, media sosial, $e$ commerce, dan download) pada tanggal 12 Agustus 2017 dan 13 Agustus 2017.

Hasil output simulasi adalah prediksi bandwidth setiap jenis perilaku pengguna internet untuk tanggal 14 Agustus 2019. Hasil prediksi tiap jenis perilaku pengguna internet yang telah didefinisikan disajikan dalam beberapa Gambar sebagai berikut :

a. SAPK (Sistem Aplikasi Pelayanan Kepegawaian)

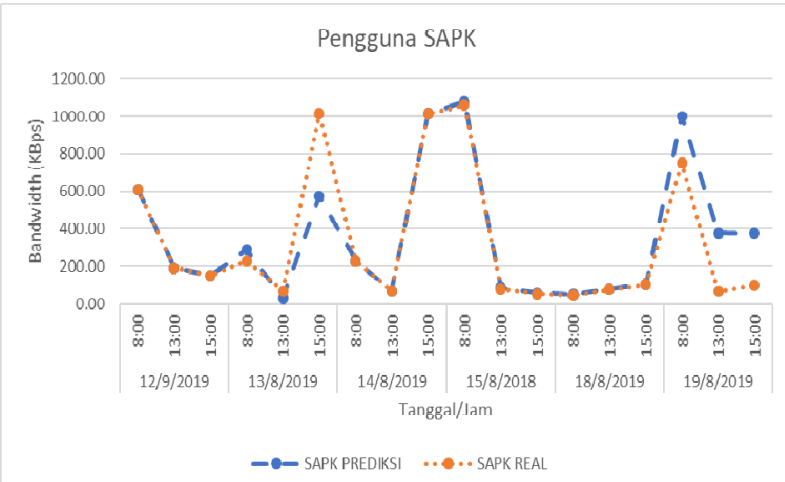

Gambar 5. Grafik prediksi bandwidth pengguna SAPK

Prediksi perilaku pengguna dengan aktifitas SAPK pada Gambar 5, menunjukkan error JST tertinggi yang terjadi pada tanggal 19 Agustus 2019, yakni pada pukul 13:00 WITA sebesar $91,58 \%$. Tingginya error tersebut dikarenakan pada waktu tersebut merupakan puncak layanan kenaikan pangkat PNS untuk periode Oktober 2019. Sebagai tambahan informasi, puncak layanan BKN untuk proses Kenaikan Pangkat PNS terjadi dua kali dalam setahun, yakni Kenaikan Pangkat periode April dan Kenaikan Pangkat periode Oktober.

b. Streaming video

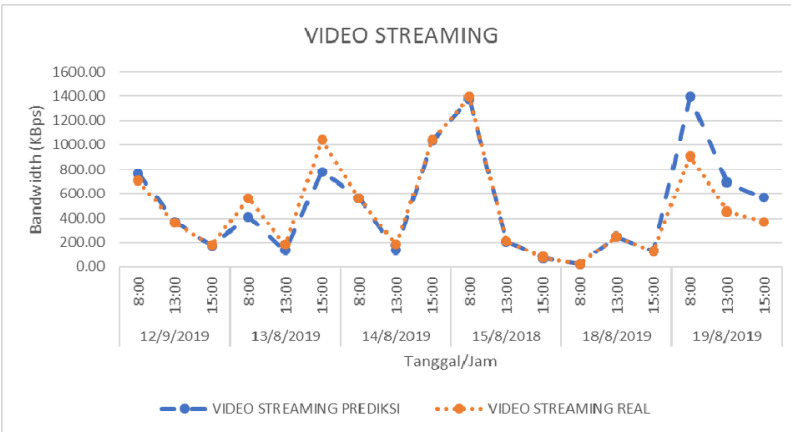

Gambar 6. Grafik prediksi bandwidth pengguna video streaming

Gambar 6 menunjukkan hasil prediksi perilaku pengguna dengan aktifitas streaming video, prediksi menunjukkan tingkat keakuratan yang tinggi. Dengan rata-rata error sebesar

Rama Beta Herdian: Manajemen Bandwidth Berdasarkan Prediksi...
$13.37 \%$ yang terjadi pada waktu jam mulai bekerja, yakni di rentang waktu pukul 8:00 WITA sampai dengan pukul 11:00 WITA. Error tersebut menunjukkan tren perilaku pengguna streaming video di Kantor Regional X BKN secara umum terjadi pada saat jam mulai kerja.

c. Streaming audio

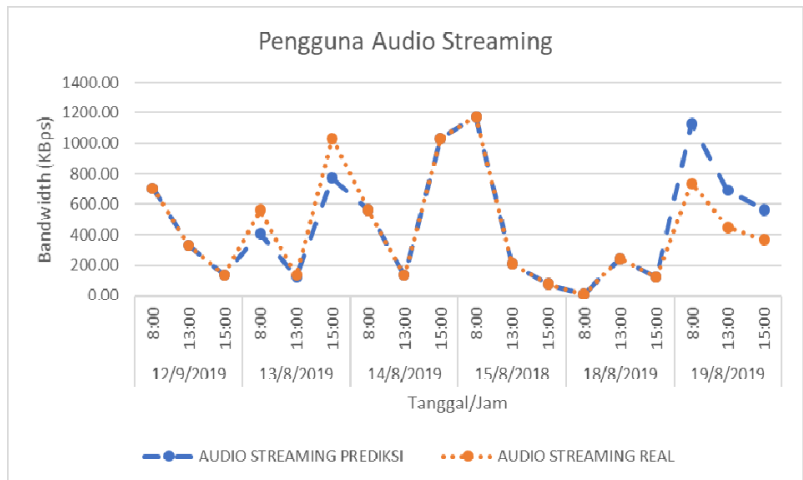

Gambar 7. Grafik prediksi bandwidth pengguna audio streaming

Prediksi perilaku pengguna dengan aktifitas streaming audio pada Gambar 7, menunjukkan tingkat error terkecil, yakni sebesar $12,42 \%$. Dimana JST yang dikembangkan dapat memprediksi dengan akurat, dikarenakan perilaku pengguna dengan aktifitas streaming audio merupakan pengguna yang konsisten dalam memanfaatkan bandwidth selama jam kerja. Hal tersebut juga menunjukkan bahwa perilaku dengan aktifitas streaming audio dilakukan oleh pengguna yang tetap.

d. Sosial Media

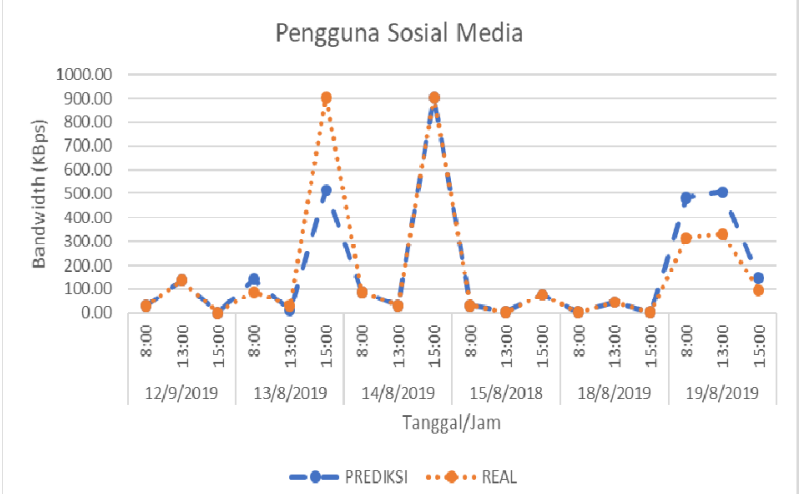

Gambar 8. Grafik prediksi bandwidth pengguna sosial media

Gambar 8 merupakan Prediksi JST terhadap perilaku pengguna dengan aktifitas sosial media, dimana hasil prediksi JST menunjukkan perilaku pengguna dengan aktifitas sosial media dimiliki oleh hampir setiap pengguna di jaringan $L A N$ Kantor Regional X BKN. Hal tersebut ditunjukkan dengan tingkat rata-rata error sebesar $22.23 \%$. Aktifitas perilaku pengguna dengan aktifitas sosial media sering dilakukan pada waktu jam istirahat, yakni antara pukul 12:00 WITA sampai dengan pukul 14:00 WITA.

\section{e. E-Commerce}

p-ISSN:1693 - 2951; e-ISSN: 2503-2372 


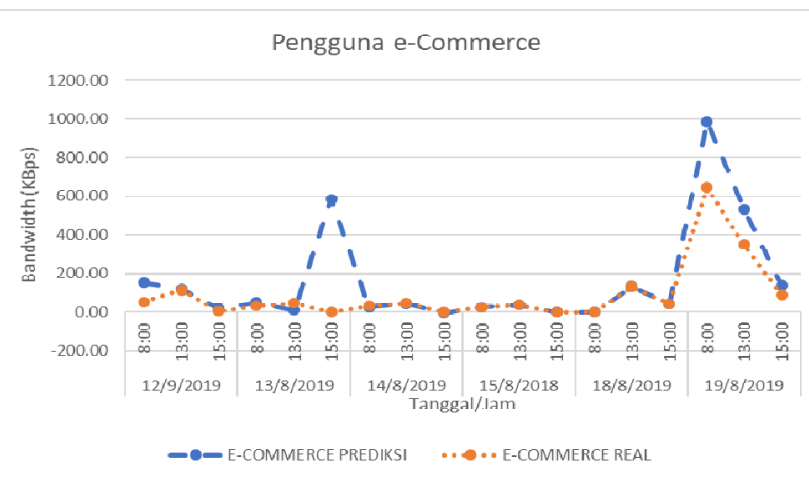

Gambar 9. Grafik prediksi bandwidth pengguna e-Commerce

Gambar 9. menunjukkan hasil prediksi JST terhadap perilaku pengguna dengan aktifitas belanja online atau sekedar membuka situs dan aplikasi belanja online. Error tertinggi terjadi pada prediksi tanggal 13 Agustus 2019 dimana JST memprediksi penggunaan bandwidth meningkat, namun data real penggunaan bandwidth cenderung turun. Prediksi JST terhadap perilaku pengguna dengan aktifitas $e$ Commerce merupakan hasil prediksi dengan rata-rata error tertinggi, yakni sebesar $31.41 \%$. hal tersebut disebabkan pemanfaatan bandwidth oleh perilaku pengguna dengan aktifitas belanja online tidak sesering aktifitas lain seperti perilaku pengguna dengan aktifitas streaming video, namun perilaku dengan jenis aktifitas e-commerce lebih dipengaruhi oleh tanggal dimana saat penghasilan atau tunjangan kinerja PNS diterima.

\section{f. Download}

Hasil prediksi JST pada perilaku pengguna dengan aktifitas download menunjukkan keakuratan yang baik dan konsisten, dimana tingkat rata-rata error sebesar $18.25 \%$, hal

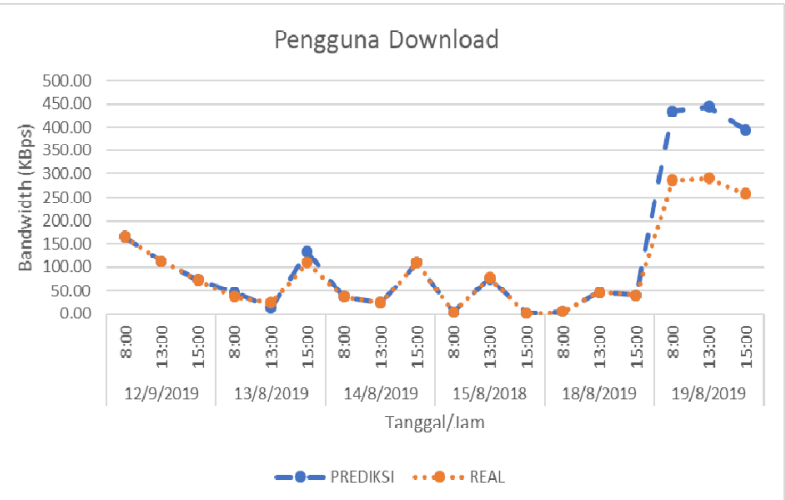

Gambar 10. Grafik prediksi bandwidth dengan aktifitas Download

ini dapat memberikan informasi bahwa perilaku pengguna dengan aktifitas tersebut memiliki tren perilaku pemanfaatan sumber daya internet yang tetap dan tidak terlalu membebani jaringan internet di Kantor Regional X BKN.

Unjuk kerja dari JST yang dikembangkan dapat dilihat dari error yang terjadi, Error adalah data bandwidth real dikurangi dengan bandwidth hasil prediksi JST. Data dengan error tertinggi terjadi pada data perilaku pengguna dengan jenis aktifitas e-commerce, yakni sebesar 201,88\% (persen) yang terjadi pada prediksi tanggal 19 Agustus 2019, dimana terjadi pada waktu menjelang berakhir kerja, yakni pukul 14:00 sampai dengan 16:00 WITA. Persentase tersebut diperoleh dari penjumlahan nilai error JST dibagi data real dikalikan $100 \%$.

Rata-rata error yang terjadi dari hasil prediksi JST pada setiap perilaku pengguna internet di Kantor Regional X BKN disajikan pada Tabel 4 berikut :

TABEL 4

UNJUK KERJA JST YANG DIKEMBANGKAN DENGAN BEBERAPA FUNGSI PELATIHAN

\begin{tabular}{|l|l|c|c|c|}
\hline No & Perilaku Pengguna & $\begin{array}{c}\text { Min error } \\
(\%)\end{array}$ & $\begin{array}{c}\text { Max error } \\
(\%)\end{array}$ & $\begin{array}{c}\text { Rata-rata } \text { error } \\
(\%)\end{array}$ \\
\hline 1 & SAPK & 0.00 & 91.58 & 17.76 \\
\hline 2 & Streaming video & 0.00 & 53.06 & 13.37 \\
\hline 3 & Streaming audio & 0.00 & 53.05 & 12.42 \\
\hline 4 & Sosial media & 0.01 & 63.72 & 22.23 \\
\hline 5 & e-Commerce & 0.00 & 201.88 & 31.41 \\
\hline 6 & Download & 0.02 & 53.06 & 18.25 \\
\hline
\end{tabular}

Error dengan nilai terkecil merupakan unjuk kerja JST terbaik ditunjukkan pada data prediksi perilaku pengguna internet dengan jenis aktifitas streaming audio yakni sebesar $12,42 \%$ (persen). Hal ini terjadi karena data yang dilatih tidak terjadi banyak perubahan signifikan dari waktu ke waktu selama proses penelitian. Namun Sebaliknya pada data dengan nilai error tertinggi akan mengalami perubahan data secara fluktuatif setiap waktu selama proses penelitian.

\section{Implementasi Hasil Prediksi}

Setelah hasil prediksi diperoleh, tahap berikutnya adalah mengimplementasikan hasil prediksi pada proses manajemen bandwidth jaringan Local Area Network (LAN) di Kantor Regional X BKN.

Implementasi bandwidth manajemen dilakukan dengan bantuan fitur queue pada sistem router Mikrotik, fitur queue merupakan alat bantu untuk melakukan manajemen bandwidth dengan cara memasukkan nilai-nilai hasil prediksi JST kedalam parameter pengaturan queue pada setiap jenis perilaku pengguna yang telah didefinisikan sebelumnya.

Berdasarkan hasil prediksi JST yang dikembangkan, kebijakan penggunaan sumber daya jaringan yang ditentukan oleh organisasi adalah $50 \%$ pengunaannya untuk Sistem Aplikasi Pelayanan Kepegawaian (SAPK) dan 50\% berikutnya digunakan untuk aplikasi selain SAPK.

Manajemen bandwidth dengan Jaringan Syaraf Tiruan (JST) merubah pola manajemen dalam memberikan batasan penggunaan sumber daya jaringan, penerapan manajemen bandwidth dapat dilakukan lebih efektif, yakni berdasarkan prediksi perilaku pengguna yang mewakili aktifitas pengguna yang telah diklasifikasikan menjadi beberapa jenis perilaku pengguna internet, dimana sebelum implementasi hasil prediksi menggunakan JST, manajemen bandwidth di $L A N$ Kanreg X BKN dilakukan dengan cara melakukan pengaturan pembatasan penggunaan bandwidth terhadap setiap IP Address pengguna yang ada di dalam jaringan.

Hasil prediksi JST terhadap bandwidth setiap jenis perilaku pengguna internet ditampilkan pada Tabel 5 berikut :

TABEL 5

JUMLAH BANDWIDTH BERDASARKAN PREDIKSI JST PADA PERILAKU PENGGUNA INTERNET

\begin{tabular}{|c|c|c|c|}
\hline Perilaku pengguna & $\begin{array}{c}\text { Bandwidth } \\
(\mathrm{KBps})\end{array}$ & $\begin{array}{c}\text { Bandwidth } \\
(\mathrm{MBps})\end{array}$ & $\begin{array}{c}\text { Penggunaan } \\
(\%)\end{array}$ \\
\hline
\end{tabular}




\begin{tabular}{|l|c|c|c|}
\hline SAPK & 2677.74 & 2.61 & 26.8 \\
\hline Streaming video & 4030.07 & 3.94 & 40.3 \\
\hline Streaming audio & 3750.31 & 3.66 & 37.5 \\
\hline Sosial media & 1414.75 & 1.38 & 14.1 \\
\hline e-Commerce & $124 \mathrm{~S} 2.43$ & 1.21 & 12.4 \\
\hline Download & 963.82 & 0.94 & 9.6 \\
\hline
\end{tabular}

yang selalu berubah dari waktu ke waktu selama proses pengambilan data penelitian, sehingga dalam melakukan prediksi terhadap perilaku pengguna internet, diperlukan jumlah data latih (data training) yang besar, semakin banyak data historis yang dilatih, semakin akurat JST dapat memprediksi bandwidth yang gunakan oleh masingmasing jenis perilaku pengguna internet.

i hasil prediksi, dimana SAPK merupakan jenis perilak pengguna internet prioritas di Kanreg $\mathrm{X}$ BKN, hanya memanfaatkan $26.8 \%$ dari total keseluruhan sumber daya jaringan. Hal ini yang menyebabkan SAPK dirasakan memiliki performa yang buruk sehingga menghambat kecepatan pelayanan kepegawaian. Data pada tabel memperlihatkan sumber daya jaringan lebih banyak digunakan untuk jenis aktifitas streaming video sebesar 40,3\% dan jenis aktifitas streaming audio sebesar $37 \%$.

Berdasarkan hasil prediksi menggunakan JST yang dikembangkan, sesuai kebijakan organisasi terkait alokasi penggunaan sumber daya jaringan. Jumlah bandwidth setiap jenis perilaku pengguna internet diatur kembali dan diterapkan pola $50 \%$ untuk SAPK dan $50 \%$ berikutnya untuk aktifitas selain SAPK, sehingga administrator jaringan memberikan batasan untuk setiap jenis perilaku pengguna internet, kemudian bandwidth setiap jenis perilaku pengguna ditentukan menjadi seperti pada Tabel 7.

Setelah diterapkannya manajemen bandwidth berdasarkan hasil prediksi menggunakan JST. Penggunaan sumber daya jaringan akan terus dipantau sampai perilaku pengguna internet mengalami perubahan tren baru. Dimana administrator sudah dapat memprediksi tren tersebut di masa yang akan datang.

TABEL 7

MANAJEMEN BANDWIDTH BERDASARKAN PREDIKSI JST PERILAKU PENGGUNA INTERNET

\begin{tabular}{|l|c|c|c|}
\hline $\begin{array}{c}\text { Perilaku } \\
\text { Pengguna }\end{array}$ & $\begin{array}{c}\text { Bandwidth } \\
(\text { KBps })\end{array}$ & $\begin{array}{c}\text { Bandwidth } \\
(\text { MBps })\end{array}$ & Penggunaan (\%) \\
\hline SAPK & 7,040 & 6.87 & 50.00 \\
\hline Streaming video & 2,837 & 2.77 & 20.15 \\
\hline Streaming audio & 2,640 & 2.58 & 18.75 \\
\hline Sosial media & 996 & 0.97 & 7.07 \\
\hline$e$-Commerce & 875 & 0.85 & 6.21 \\
\hline Download & 678 & 0.66 & 4.82
\end{tabular}

Data hasil prediksi menggunakan JST juga menunjukkan jumlah keseluruhan penggunaan sumber daya jaringan ratarata adalah sebesar 13,7 MBps, nilai tersebut merupakan hasil penjumlahan dari seluruh rata-rata penggunaan bandwidth oleh setiap jenis perilaku pengguna, dan jumlah tersebut melebihi bandwidth yang disediakan saat ini yakni sebesar 10 MBps. Informasi tersebut menjadi dasar untuk merencanakan peningkatan bandwidth internet dari yang ada saat ini menjadi 15 MBps di tahun anggaran berikutnya.

\section{HASIL DAN PEMBAHASAN}

Dari hasil penelitian yang telah dilakukan dapat disimpulkan beberapa hal sebagai berikut :

A. Perilaku pengguna internet dalam memanfaatkan bandwidth yang tersedia cukup beragam, dengan perilaku

Rama Beta Herdian: Manajemen Bandwidth Berdasarkan Prediksi...

B. Sesuai hasil prediksi dapat ditarik kesimpulan bahwa perilaku pengguna dengan aktifitas streaming video merupakan pengguna sumber daya jaringan internet terbesar di Kantor Regional X BKN. Prediksi penggunaan bandwidth tertinggi oleh pengguna dengan aktifitas streaming video terjadi dua kali, yakni sebesar 1.393 KBps yaitu pada tanggal 15 Agustus 2019 dan 19 Agustus 2019 pada jam yang sama yaitu pada waktu mulai jam kerja (08:00 sampai dengan 10.59 WITA). Hal tersebut menunjukkan tren perilaku pengguna streaming video.

C. Dalam rentang waktu tanggal 15 Agustus 2019 sampai dengan 19 Agustus 2019 hasil prediksi penggunaan bandwidth menunjukkan rata-rata terbesar adalah pengguna internet dengan aktifitas streaming video yakni 504,3 KBps, sedangkan pengguna internet dengan aktifitas download merupakan pengguna bandwidth terkecil dengan rata-rata penggunaan bandwidth sebesar 120,4 KBps.

D. Prediksi berdasarkan perilaku pengguna internet menggunakan Jaringan Syaraf Tiruan dapat digunakan memprediksi kebutuhan bandwidth internet untuk tahun berikutnya. Hasil prediksi menunjukkan bahwa kebutuhan bandwidth internet di Kantor Regional X BKN adalah sebesar 13,7 MBps hingga 15 MBps.

E. Secara keseluruhan hasil prediksi dengan menggunakan Jaringan Syaraf Tiruan menunjukkan prediksi bandwidth yang cukup akurat pada saat diuji pada jaringan internet di Kanreg X BKN, dimana hasil pengujian menunjukkan pendekatan terhadap data penggunaan real bandwidth, dengan rata-rata error keseluruhan jenis perilaku pengguna sebesar $17.37 \%$. Hasil prediksi tersebut dapat digunakan oleh administrator jaringan sebagai dasar untuk menentukan bandwidth setiap jenis perilaku pengguna internet. Gambar 11 berikut menunjukkan pemanfaatan bandwidth sebelum dan sesudah implementasi hasil prediksi JST.

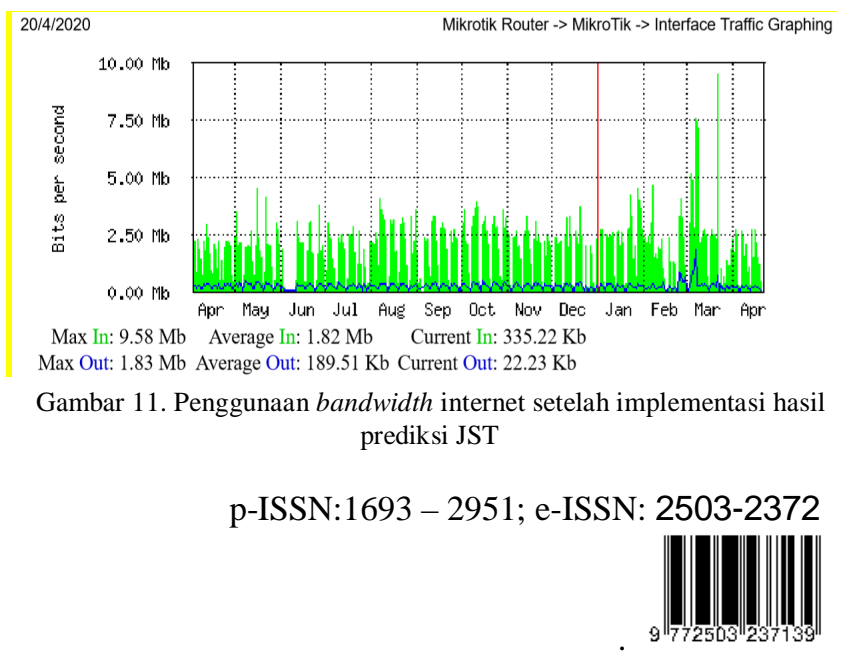


Implementasi hasil prediksi JST dimulai bulan Januari 2020, tampak dalam Gambar 11 yang diambil pada tanggal 20 April 2020, jumlah pemanfaatan bandwidth tertinggi di bulan Maret 2020 dan April 2020 rata-rata mencapai 9,58 MBps, dimana hal tersebut tidak pernah terjadi sebelum implementasi hasil prediksi JST, hal ini menunjukkan bahwa manajemen bandwidth berdasarkan prediksi perilaku pengguna menggunakan JST dapat mengoptimalkan pemanfaatan sumber daya jaringan, sehingga manajemen jaringan internet di Kanreg X BKN dapat dilakukan dengan baik sesuai kebijakan dan tujuan organisasi

F. Penelitian ini memungkinkan untuk dikembangkan dengan menambah jumlah data latih yang lebih besar untuk meningkatkan keakuratan JST dalam melakukan prediksi jenis perilaku pengguna internet. Penambahan jenis perilaku pengguna internet dengan aktifitas yang lain, misal perilaku pengguna dengan aktifitas $P 2 P$ (Peer to Peer) dan cloud sharing dapat dilakukan untuk memprediksi serta mengetahui pola dan tren baru terhadap aktifitas tersebut.

G. Untuk mengembangkan sistem manajemen bandwidth berdasarkan perilaku pengguna yang dapat beradaptasi terhadap tren perilaku pengguna baru dan berjalan secara periodik, maka saran penelitian kedepannya adalah dengan menambahkan sebuah sistem yang dapat mendokumentasikan data traffic yang akan digunakan sebagai data latih JST, data tersebut diambil dari router secara otomatis dan dapat diatur oleh sistem sesuai kebutuhan. Sehingga secara keseluruhan akan menjadi sistem yang dapat berjalan sendiri serta dapat diterapkan untuk memprediksi jenis perilaku pengguna yang lain dengan lebih baik.

\section{UCAPAN TERIMA KASIH}

Terimakasih kepada Kepala Kantor Regional dan Kepala Bidang Informasi Kepegawaian Kantor Regional X Badan Kepegawaian Negara Denpasar yang telah memberikan kesempatan untuk melakukan penelitian ini.

\section{REFERENSI}

[1] A. Callado et al., "A Survey on Internet Traffic Identification," IEEE Commun. Surv. Tutor., vol. 11, no. 3, pp. 37-52, rd 2009, doi: 10.1109/SURV.2009.090304.
[2] M. Hemmati, B. McCormick, and S. Shirmohammadi, "Fair and Efficient Bandwidth Allocation for Video Flows Using Sigmoidal Programming," in 2016 IEEE International Symposium on Multimedia (ISM), Dec. 2016, pp. 226-231, doi: 10.1109/ISM.2016.0052.

[3] M. Amiri, H. Al Osman, and S. Shirmohammadi, "Game-aware bandwidth allocation for home gateways," in 2017 15th Annual Workshop on Network and Systems Support for Games (NetGames), Jun. 2017, pp. 1-3, doi: 10.1109/NetGames.2017.7991546.

[4] A. Badea, V. Croitoru, and D. Gheorghică, "Computer networks security based on the detection of user's behavior," in 2015 9th International Symposium on Advanced Topics in Electrical Engineering (ATEE), May 2015, pp. 55-60, doi: 10.1109/ATEE.2015.7133679.

[5] B. Leng, J. Liu, H. Pan, S. Zhou, and Z. Niu, "Topic model based behaviour modeling and clustering analysis for wireless network users," in 201521 st Asia-Pacific Conference on Communications (APCC), Oct. 2015, pp. 410-415, doi: 10.1109/APCC.2015.7412547.

[6] A. Sinha, K. Mitchell, and D. Medhi, "Flow-level upstream traffic behavior in broadband access networks: DSL versus broadband fixed wireless," Nov. 2003, pp. 135-141, doi: 10.1109/IPOM.2003.1251235.

[7] H. Marques-Neto, L. Rocha, P. Guerra, J. Almeida, W. Meira Jr, and V. Almeida, "Characterizing broadband user behavior," Nov. 2004, doi: $10.1145 / 1026763.1026767$.

[8] J. Ma and Y. Zhang, "Research on Trusted Evaluation Method of User Behavior Based on AHP Algorithm," in 2015 7th International Conference on Information Technology in Medicine and Education (ITME), Nov. 2015, pp. 588-592, doi: 10.1109/ITME.2015.39.

[9] H. Harsono, M. Khambali, and A. W. Muhammad, "Klasifikasi Paket Jaringan Berbasis Analisis Statistik dan Neural Network," J. Inform. J. Pengemb. IT, vol. 3, no. 1, pp. 67-70, Jan. 2018, doi: 10.30591/jpit.v3i1.764.

[10] Suyanto, DATA Mining untuk Klasifikasi dan Klasterisasi, 1st ed., vol. Cet. 1. Bandung: INFORMATIKA Bandung, 2017.

[11] B. Santosa, "Data mining teknik pemanfaatan data untuk keperluan bisnis," Yogyak. Graha Ilmu, vol. 978, no. 979, p. 756, 2007.

[12] N. A. Al-Sammarraie, Y. M. H. Al-Mayali, and Y. A. Baker El-Ebiary, "Classification and diagnosis using back propagation Artificial Neural Networks (ANN)," in 2018 International Conference on Smart Computing and Electronic Enterprise (ICSCEE), Jul. 2018, pp. 1-5, doi: 10.1109/ICSCEE.2018.8538383.

[13] A. Hasim, "Prakiraan Beban Listrik Kota Pontianak Dengan Jaringan Syaraf Tiruan (Artificial Neural Network)," 2008, Accessed: Sep. 02, $2019 . \quad$ [Online]. Available: http://repository.ipb.ac.id/handle/123456789/41400.

[14] W. Setiawan and S. A. Asri, "APLIKASI JARINGAN SYARAF TIRUAN PERAMBATAN BALIK PADA PENGENALAN ANGKA TULISAN TANGAN," Maj. Ilm. Teknol. Elektro, vol. 4, no. 2, Jul. 2005, Accessed: Jul. 12, 2019. [Online]. Available: https://ojs.unud.ac.id/index.php/JTE/article/view/209.

[15] "RegexOne - Learn Regular Expressions - Lesson 1: An Introduction, and the ABCs." https://regexone.com/ (accessed Sep. 11, 2019). 